\title{
The anatomy of cervical sympathetic ganglia in Saanen goats*
}

\author{
Murat KABAK ${ }^{1}$, Burcu ONUK ${ }^{1}$, Sedef SELVILER SIZZER ${ }^{2}$, Yonca Betil KABAK ${ }^{3}$ \\ Ondokuz Mayıs University, Faculty of Veterinary Medicine, ${ }^{1}$ Department of Anatomy; ${ }^{2}$ Graduate School of Health Sciences; \\ ${ }^{3}$ Department of Pathology, Samsun, 55139, Turkey.
}

Summary: Sympathetic ganglions located in the cervical region are important organs that make the final synapse of the sympathetic nerve fibers reached to the head, neck, and forelimbs. As far as we know, there are not any anatomical data about cervical sympathetic ganglia in Saanen goat. In this study, we determined the nerve branches separated from the ganglia and the location of the ganglia. We also determined the expression of some enzymes and proteins such as tyrosine hydroxylase (TH), dopamine $\beta$-hydroxylase $(\mathrm{D} \beta \mathrm{H})$, neuropeptide Y (NPY) and substance P (SP) in ganglia. Ganglion cervicale craniale (GCC) was on the medial side of bulla tympanica. Mainly branches named as nn. carotici interni, $\mathrm{n}$. jugularis and nn. carotici externi was found to be separated from this ganglion and thin branches joined to the nearby nerve. It was found that $\mathrm{n}$. vertebralis, the two branches that constitute the ansa subclavian, and the thin nerve branches involved in the surrounding tissues and organs separated from ganglion cervicothoracicum (GCT) that located in the first intercostal space. A total of five ganglion cervicale medium (GCM) found at the junction of the two branches forming the ansa subclavia. Another ganglion was not found on where cervical part of truncus sympathicus in all dissections and histological examinations. D $\beta \mathrm{H}, \mathrm{TH}, \mathrm{NPY}$ and SP were revealed to be express in all ganglia. D $\beta \mathrm{H}$ and NPY in CCG, TH in MCG, $\mathrm{D} \beta \mathrm{H}, \mathrm{NPY}$ and TH in GCT were found to be more intense staining.

Keywords: Anatomy, immunohistochemistry, Saanen goat, sympathetic ganglia.

\section{Saanen keçilerinde servikal sempatik ganglion'ların anatomisi}

Özet: Cervical bölgede yer alan sempatik ganglion'lar baş, boyun ve ön ektremite'lere giden sempatik sinir liflerinin son sinaps yaptığı önemli organlardır. Saanen keçisinde servikal sempatik ganglion'lara ait anatomik bilgiye rastlanılmadı. Bu nedenle, bu çalışma ile bahsi geçen ganglion'ların yeri, ganglion'dan ayrılan sinir kolları ve ganglion'lardaki dopamin $\beta$-hidroksilaz (D $\beta H)$, tirozin hidroksilaz (TH), Neuropeptid Y (NYP) ve Substans P (SP) gibi bazı enzim ve protein expresyonu belirlendi. Bulla tympanica'nın medial'inde yer alan ganglion cervicale craniale (GCC)'den başlica nn. carotici interni, n. jugularis, n. caroticus externus ve çevre sinirlere katılan ince kollar ayrıldığı görüldü. Birinci interkostal aralıkta yer alan ganglion cervicothoracicum (GCT)'dan başlıca n. vertebralis, ansa subclavia’yı oluşturan iki kol ve çevre doku ve organlara katılan ince sinir kollarının ayrıldığı belirlendi. Ansa subclavia'yı oluşturan iki kolun birleşim yerinde toplam 5 adet ganglion cervicale medium (GCM)'a rastlandı. Yapılan tüm diseksiyon ve histolojik incelemelerde truncus symphaticus'un cervical bölümünde başka bir gangliona rastlanmadi. D $\beta H$, TH, NPY ve SP'nin tüm ganglion'larda exprese olduğu, GCC'de D $\beta H$ ve NPY'nin, GCM'da TH'ın, GCT'da D $\beta H$, NPY ve TH'ın daha yoğun boyanma gösterdiği belirlendi.

Anahtar sözcükler: Anatomi, immunohistokimya, Saanen keçisi, sempatik ganglion.

\section{Introduction}

In the sympathetic nervous system, two neurons function between the center and the effector organ. Synapses between these neurons occur in the ganglion (35). GCC and GCT are always present in domestic mammals, whereas the presence of GCM varies with species or even individuals $(14,16,35)$. The presence of ganglion, also named to as ganglia intermedia, has been reported in some species (27).
The immunoreactivity of enzymes such as TH and $\mathrm{D} \beta \mathrm{H}$ and proteins such as NYP and SP known to be expressed by sympathetic neurons in the ganglia trunci sympathici have been reported $(2,3,5,8,13,24)$. NPY that originated from the sympatho-adrenomedullary nervous system has a vasoconstrictive and mitogenic effect on blood vessels. It functions in blood pressure regulation and angiogenesis (23). SP which performs functions such as pain perception, emotional behavior, stress, smooth muscle contraction and saliva production

\footnotetext{
* Some parts of this study was presented as summary in the IX. (Elazığ, 2010) and X. (Afyon, 2017) National Veterinary Anatomy Congress and The 3th International VETIstanbul Group Congress (Sarajevo, Bosnia and Herzegoviana, 2016) and 1st International Veterinary Anatomy Congress of Turkey (Afyon, 2017).
} 
has a wide spread in the body $(9,10,11,36)$. In addition, $\mathrm{SP}$ in the neuropeptide structure is also found in preganglionic neurons of sympathetic ganglia (12). Catecholamine neurons, such as dopamine, norepinephrine and epinephrine contain the TH enzyme. After this enzyme converts tyrosine to a composition called as dopa, dopa is also turned into dopamine neurotransmitter. In addition to $\mathrm{TH}$, neurons that use norepinephrine as a neurotransmitter also have the $\mathrm{D} \beta \mathrm{H}$ which converts dopamine to norepinephrine (1).

It is stated that cause dysfunctions in the head, neck and forelimb of pathological conditions that may occur in cervical sympathetic ganglia due to some metabolic diseases (21) or arterial insufficiency (28). One of them is Horner's syndrome (29), the other is the suppression of melatonin release expressed in the pineal gland (26). Damages occurred in GCT for different reasons can lead to arrhythmias in the heart (22).

The literature on the anatomy of the cervical sympathetic ganglia that have important functions is not encountered in Saanen goats. The purpose of this study was to determine the location and size of cervical sympathetic ganglia, nerve branches separated from them, and also demonstration of the presence of sympathetic neurons via $\mathrm{D} \beta \mathrm{H}, \mathrm{NYP}, \mathrm{TH}$ and $\mathrm{SP}$ antibodies known to be expressed by sympathetic neurons in the ganglia

\section{Materials and Methods}

In this study, a total of 14 samples were evaluated by examining each half of 7 adult female Saanen goats separately. Our study was approved by our local Ondokuz Mayıs University Animal Experiment Local Ethical Committee (Ethics committee number: 2012/28). After perfusion, all the materials were fixed with $10 \%$ formaldehyde solution. The dissections were performed under a stereomicroscope (Olympus SZ61 TRC). Photos were taken with a digital camera (Olympus C-5060). Measurements were measured with digital caliper (Mitutoyo, Japan). These measurements were analyzed via ordinary least squares (OLS) technique. Nomina Anatomica Veterinaria (30) was used for anatomic denomination.

Four blocks from each of GCC, GCM and GCT were prepared for histological and immunohistochemical examinations. Tissue sections were in $5 \mu \mathrm{m}$ thick. The prepared sections were stained with haematoxylin-eosin (H\&E) and were processed for immunohistochemical investigation with primary antibodies Tyrosine Hydroxylase Polyclonal antibody (PA1-4679, Thermo Fisher Scientific, USA), anti-Neuropeptide Y antibody (PA5- 19568, Thermo Fisher Scientific, USA), Substance P Polyclonal antibody (Bs-0065R, Bioss, USA) and AntiDopamine $\beta$ Hydroxylase antibody (Millipore AB 1585, USA) by using standard streptavidin-biotin peroxidase complex method (SBPC) with a commercial kit (Zymed, USA). The reaction product was visualized by aminoethylcarbazole (AEC) chromogen (Zymed, USA) and counterstained with Mayer haematoxylin. Immunohistochemistry results were interpreted using a light microscope (Nikon Eclipse E600). For the quantification of the immunological staining in the tissue the analysis was initiated on the basis of the high intensity reaction fields. All of the sections were examined at a magnification of $400 \mathrm{X}$. The staining densities of cells that are positive in each area [(0) no reaction; (1) poor; (2) medium; (3) intense staining] was determined.

In addition, the blocks prepared for determination of whether or not any ganglions in the cervical part of the truncus sympathicus between GCC and GCM or GCT were examined by staining with $\mathrm{H} \& \mathrm{E}$ (25).

\section{Results}

GCC (Figure 1-a) and GCT (Figure 2-a) were found to be present in all examined Saanen goats. While GCM (Figure 2-b) existed in some materials, there was no another ganglion in the cervical part of the truncus sympathicus in all examined materials.

Ganglion cervicale craniale: GCC located in the ventral of art. atlantooccipitalis, at the medial and ventral of bulla tympanica and at the caudal of $1 \mathrm{nn}$. retropharyngei mediales. The average length, width, and thickness of this ganglion, which was generally oval (10/14) and sometimes spindle (4/14) shaped, were determined as 9.35 $\pm 0.99 \mathrm{~mm}, 4.03 \pm 0.44 \mathrm{~mm}$ and $3.21 \pm 0.32 \mathrm{~mm}$, respectively.

It was observed that two nerves separated from the cranial half of the GCC. One of these was nn. carotici interni (Figure 1-b), and the other was n. jugularis (Figure 1-c). It was determined that the $n$. jugularis joined to the n. glossopharyngeus (Figure 1-d) and n. vagus (Figure 1e). The nn. carotici interni usually established of two $(11 / 14)$, very rarely one $(2 / 14)$ or three $(1 / 14)$ thin nerve branches. This nerve which accompanied the a. caroticus internus after leaving the ganglion constituted the plexus caroticus internus around this artery. The nn. carotici interni ended in sinus cavernosus.

It was determined that generally (10/14) 3, sometimes (4/14) 4 nerve branches separated from the ventral half of the ganglion. One of these joined to ramus pharyngeus (Figure 1-e ') which separated from n. vagus, the other one participated directly n. vagus. Nervus caroticus externus originated as a single nerve from the ventral side of the ganglion (Figure 1-f) was observed to separeted two branches (4 samples) immediately after the distinction. In three samples, these branches formed plexus caroticus externus around the a. caroticus externus the same named artery. In one sample, while one of the branches shaped the plexus, the other participated in the $\mathrm{n}$. laryngeus cranialis (Fig. 1-f'). The nerve branches directly participating in cervical nerves from GCC could not observed in this study. 
Figure 1. Medial view of GCC in Saanen goat.

a) GCC, b) nn. carotici internii, c) n. jugularis, d) n. glossopharyngeus, d') the branch that separates from n. glossopharyngeus and extented to glomus caroticus, e) n. vagus, e') ramus pharyngeus of n. vagus, e") n. laryngeus cranialis, f) $n$. caroticus externus, $f^{\prime}$ ) the branch that separates from the $n$. caroticus externus and joins to the $\mathrm{n}$. laryngeus cranialis, g) cervical part of tr. sympatheticus, h) branch that separates from CCG and joined to both n. vagus and the ramus pharyngeus of $n$. vagus, i) n. hypoglossus, apa) a. pharygea ascendes, acc) a. carotis communis, ace: a. carotis externa, aci) a. carotis interna, bar) $1 \mathrm{~cm}$.

Şekil 1. Saanen keçisinde GCC'nin medial görünümü

a) CCG, b) nn. carotici internii, c) n. jugularis, d) n. glossopharyngeus, d') n. glossopharyngeus'tan ayrilan ve glomus caroticus'a uzanan kol, e) n. vagus, e') $n$. vagus'un ramus pharyngeus'u, e') $n$. laryngeus cranialis, f) $n$. caroticus externus, f') n. caroticus externus'tan ayrilan ve n. laryngeus cranialis'e katılan kol, g) tr. sympatheticus'un servikal bölümü, h) CCG'den ayrilan ve hem $n$. vagus'a hem de onun ramus pharygeus'una katılan kol, i) n. hypoglossus, apa) a. pharygea ascendes, acc) a. carotis communis, ace) a. carotis externa, aci) a. carotis interna, bar) $1 \mathrm{~cm}$.

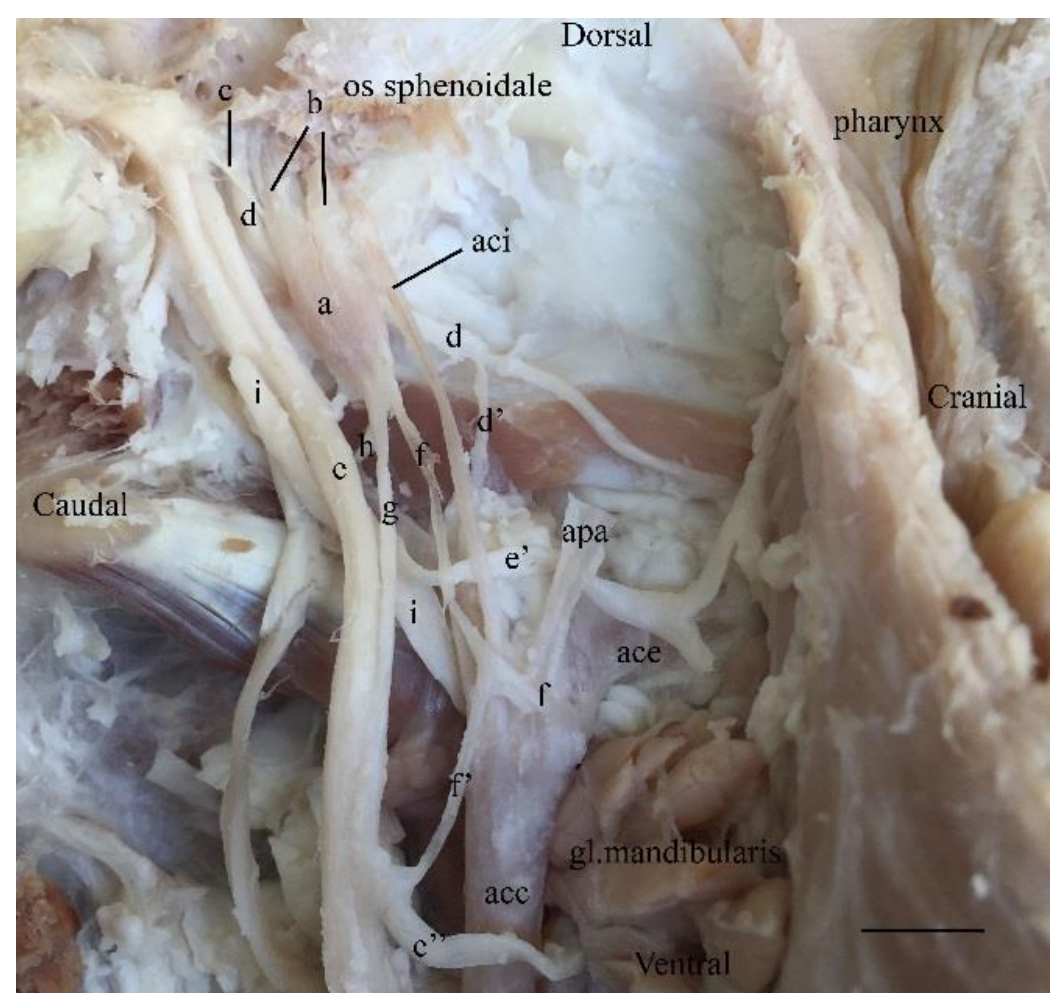

Figure 2. The view from left side of GCT and GCM in Saanen goat.

a) GCT, b) GCM, c) cranial branch of ansa sublavia, c') caudal branch of ansa sublavia, d) branch that separated from GCM and accompanied to a. subclavia sinistra, e) $n$. vertebralis, f) the branch joined from GCT to T1 n.spinalis, g) the branch that separates from caudovenral of GCT and joined to plexus aorticus, h) the branch that separates from ventral of GCT and dispersing to heart at the level of the left auricula, i) the branch that separated from ventral of GCT and dispersed to heart, j) the branch that separates from GCT and extented a long with a. sublavia sinistra, $\mathrm{k}$ ) branch that dispersed on $\mathrm{m}$. longus colli, accs) a. carotis communis sinistra, ass) a. subclavia sinistra, np) n. phrenicus, nv) n. vagus, ts) cervical part of the truncus sympathicus, C6, C7, C8) ventral branches of the $6^{\text {th }}, 7^{\text {th }}$, and $8^{\text {th }} \mathrm{nn}$. cervicalis spinalis, T1, T2, T3) ventral branches of the $1^{\text {st }}$, $2^{\text {nd }}$ and $3^{\text {rd }} \mathrm{nn}$. thoracalis spinalis, $*$ : rami

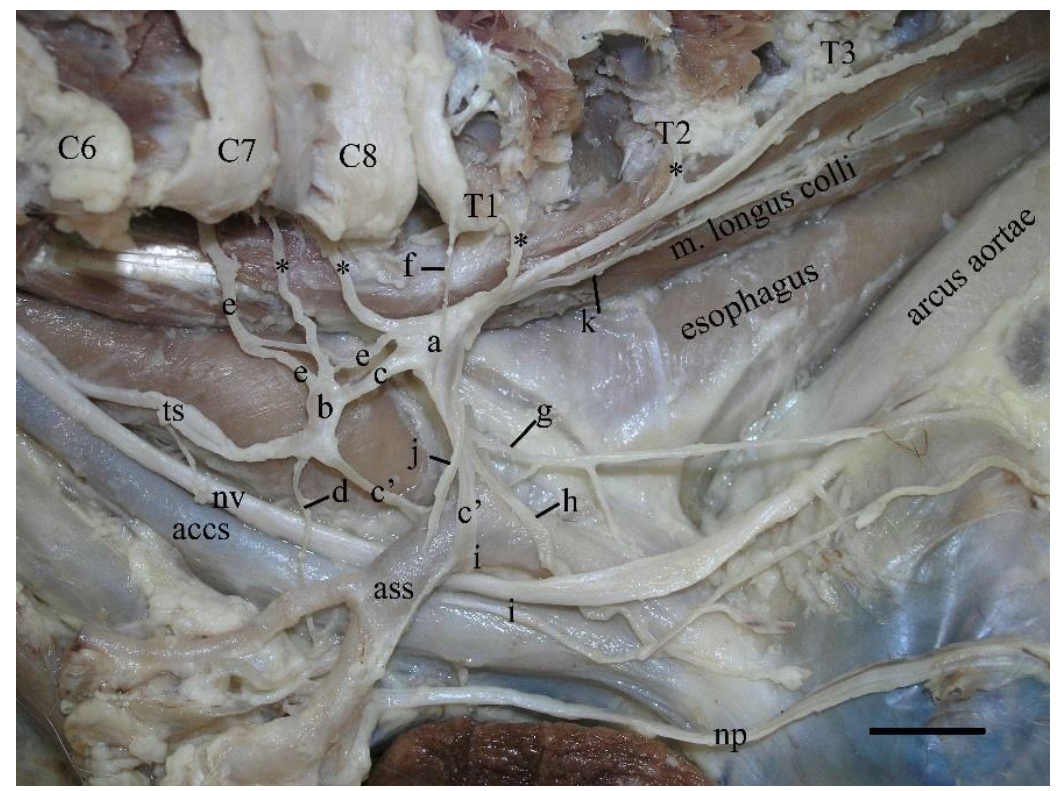
communicantes

Şekil 2. Saanen keçisinde CTG ve MCG'nin sol taraftan görünümü.

a) CTG, b) MCG, c): ansa sublavia'nın cranial kolu, c') ansa subclavia'nın caudal kolu, d) CTG'dan ayrılan ve a. subclavia sinistra'nın kolları ile seyreden kol, e) n. vertebralis, f) CTG'dan T1 spinal sinire katılan kol, g) CTG'un caudoventral'inden ayrilan ve plexus aorticus'a katılan kol, h) CTG'un ventral'inden ayrılan ve auricula sinistra düzeyinde kalbe dağılan kol, i) CTG'un ventral'inden ayrılan ve kalbe dağılan kol, j) CTG'dan ayrılan ve a. sublavia sinistra'ya boyunca uzanan kol, k) m. longus colli üzerinde seyreden sinir kolu, accs) a. carotis communis sinistra, ass) a. subclavia sinistra, np) n. phrenicus, nv) n. vagus, ts) tr. sympathicus'un boyun bölümü C6, C7, C8: 6. 7. ve 8. cervical spinal sinirlerin ventral kolları T1, T2, T3: 1. 2. ve 3. thoracal spinal sinirlerin ventral kolları *: rami communicantes. 


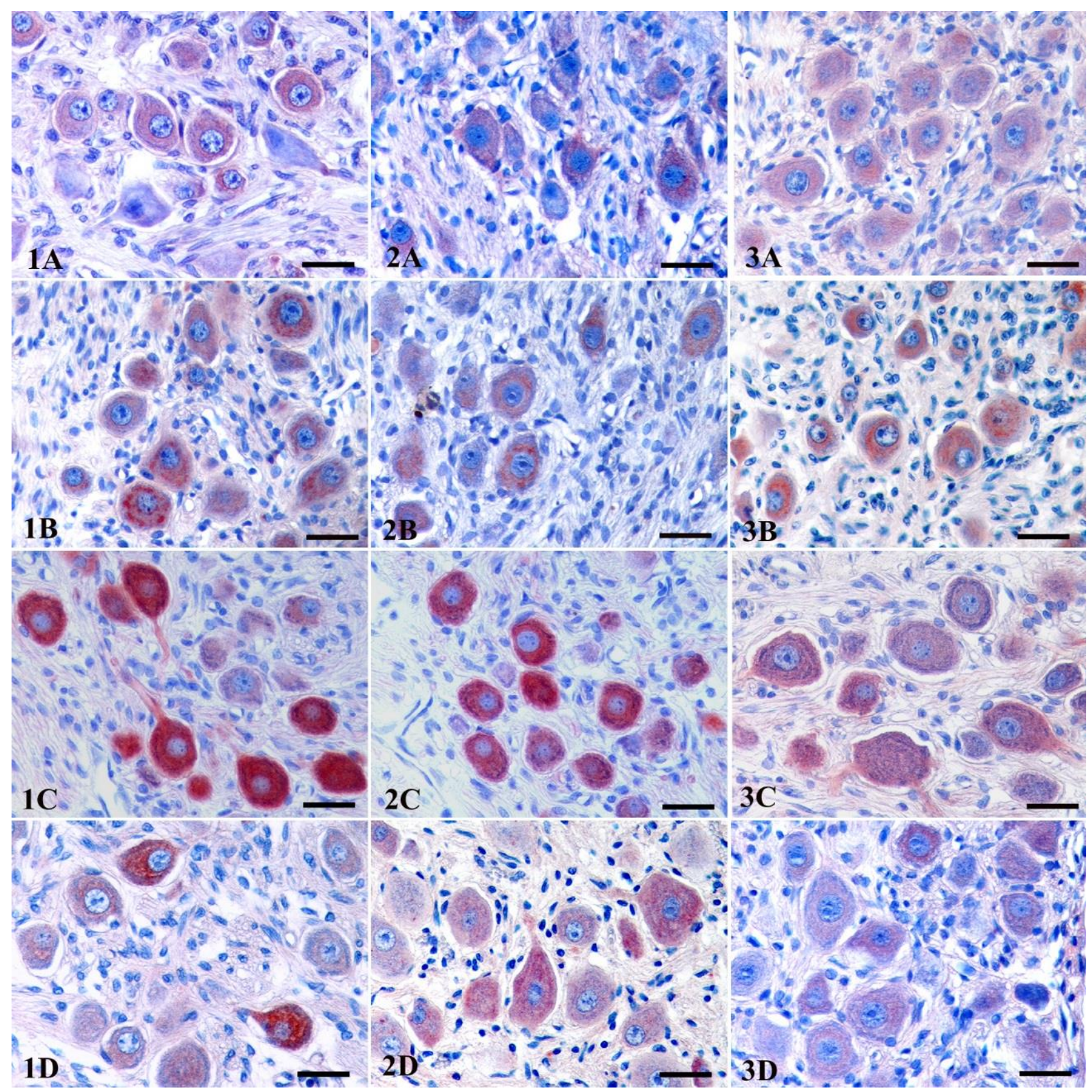

Figure 3. The expression of dopamine- $\beta$-hydrohsiase (A), Neuropeptide Y (B), Tyrosine hydroxylase (C) and Substance P (D) in GCC (1), GCM (2), GCT (3), bar), $25 \mu \mathrm{m}$.

Şekil 3. CCG (1), MCG (2), CTG (3)'da Dopamin - $\beta$-hidroksilaz (A), Neuropeptid Y (B), Tirozin hidroksilaz (C) ve Substans P (D)'nin ekspresyonu, bar), $25 \mu \mathrm{m}$.

Ganglion cervicale medium: The oval-shaped GCM (Figure 2-b) was at the entrance of the apertura thoracis cranialis and where join of the ansa cranialis (Figure 2-c) and ansa caudalis (Figure 2-c') of CTG. The length, width and thickness average measurements of GCM that observed as total 5 numbers (three left, two right) were in $4.78 \pm 0.46 \mathrm{~mm}, 4.25 \pm 0.22 \mathrm{~mm}$ and $2.72 \pm 0.46 \mathrm{~mm}$, respectively. Whereas some branches that separated from GCM added to a. subclavia dextra and a. subclavia sinistra (Figure 2-d), it was determined that some branches extended to the heart. In one sample, one branch that came from the GCM joined to n. vertebralis (Figure 2-e). In same sample, one branch which separated from ventral branch of $7^{\text {th }}$ nervus cervicalis participated to GCM (Figure 2- *).

Ganglion cervicothoracicum: The GCT located in first intercostal space (Figure 2-a) and between the $\mathrm{m}$ longus colli and esophagus on the left, $\mathrm{m}$ longus colli and trachea on the right. GCT was triangular, round or spindle shape. It observed to be formed by the combination of the last cervical ganglion sympathica and first thoracal ganglion sympathetica (in a sample, the second thoracal 
ganglion sympathetica also joined). Thin nerve branches involved from GCT to ventral branches of 8th cervical $n$. spinalis and first thoracal n. spinalis (Figure 2-f). The mean length, width and thickness measurements of GCT were in $12.84 \pm 1.07 \mathrm{~mm}, 5.56 \pm 0.93 \mathrm{~mm}$ and $3.26 \pm 0.66$ $\mathrm{mm}$, respectively.

It was observed that thin nerve branches added from GCC to the vertebral nerve (Figure 2-e), to ansa cranialis (Figure 2-c) and ansa caudalis (Figure 2-c') forming ansa subclavia and in addition, to plexus aorticus (Figure 2-g) and heart (Figure 2-h-i). Apart from these branches, there were one (Figure 2-j) or two more branches separating from the ventral of the ganglion. Some branches (Figure 2-d) originating from GCM also added to these branches that accompany with a. subclavia sinistra and dextra and forming perivascular plexus on them. It was seen to participation of one branch (Figure 2-e) from GCM to n. vertebralis in only one sample.

Neurons in the cervical sympathetic ganglion stained immunopositive with $\mathrm{D} \beta \mathrm{H}, \mathrm{NPY}, \mathrm{SP}$ and $\mathrm{TH}$ antibodies (Figure 3). In all three ganglia, the cytoplasm of some neurons with $\mathrm{D} \beta \mathrm{H}$ antibody stained medium intensity and homogeneous character. It was observed that the staining with NPY antibody in the perinuclear region of some neurons determined to be granular. Although the cytoplasm of neurons with SP antibody was homogeneous staining, it was noted that the intensity of staining in all three ganglia was different. It was determined with $\mathrm{TH}$ antibody that almost all neurons in each of the three ganglia reacted immunopositive and the intensity of staining of most neurons was intense.

\section{Discussion and Conclusion}

It is important to know the location of the sympathetic ganglia and the distribution of the nerves separated from them, as the conduction disorders in postganglionic nerve fibers in the sympathetic nervous system may cause important clinical symptoms $(18,19)$.

The GCC was oval and spindle shaped in our study. This stiuation was similar to literature $(6,14,15)$ The dimensions of the GCC have been reported in goat (27), Tibetan cattle (34) and roe deer (15). In this study, the width and thickness measurements of the GCC were similar to those reported as $3.67 \mathrm{~mm}$ and $3.07 \mathrm{~mm}$ in the roe deer (15). The length of the ganglion in the Saanen goat was lower than the value reported as $13.85 \mathrm{~mm}$ in the roe deer (15), as and higher than the value reported as 8 $\mathrm{mm}$ in the goat (27).

The separating of three main nerves as the nn. carotici interni, n. caroticus externus and n. jugularis from the GCC and the formations a plexus around the same named arteries of branches separated from nn. carotici interni and n. caroticus externus was compatible with the literature $(6,14,31,34)$. It has been reported in the literature $(6,7,15,27,31)$ that there are differences in the numbers of the nn. carotici interni and $n$. caroticus externus. In this study, while the separating as usually to two branches of the nn. carotici interni was similar to literature $(7,27)$, as very rarely, the separating of the single branch was created a difference. In this study, the separation as a single branch of the $\mathrm{n}$. caroticus externus from the ventral of GCC was consonant to literature. (6, 7, $27,31)$. In four materials, the nerve which separated as a single branch from the ganglion immediately divided to two. This situation was similar to state of Kabak and Onuk (15).

In the literature $(14,15)$, it has been reported that the nerve branch separating from GCC is involved to the $\mathrm{n}$. laryngeus cranialis. In this study, although one nerve that separating from the ganglion and joined directly to $n$. laryngeus cranialis was not presence, the participation to the mentioned nerve of the one branch separating from the n. caroticus externus and cervical part of the truncus sympathicus constituted an important difference.

The presence of connecting branches one $(6,15,27$, $31,35)$ two or three (14) between the GCC and the nn. cervicales is mentioned. The absence of any linkage in this study was suggest that this was due to dissection errors.

Differences are reported about the presence of GCM at the junction of ansa cranialis and ansa caudalis in the literature (27). A total of 5 numbers GCM, 3 on the left and 2 on the right were observed in this study. In cervical part of truncus sympathicus of goat, the GCM and ganglia intermedia have reported by Getty (27). While it was only present GCM in our study, the ganglia intermedia were not found. This situation was consistent with the reported in the roe deer (16).

The localization of GCT within the first intercostal space in the Saanen goat was consistent with the literature $(16,27,32,33)$. Although the shaped of GCT is reported as oval, star, half moon, pear and inverted L letter (17, 27, $32,33)$, the appearance like as triangular and spindle in this study was similar to roe deer (16). The length, width and thickness measurements of the GCTs reported in different species $(16,17,27,32,33)$ determined to be $12.84 \times 5.56 \times 3.26 \mathrm{~mm}$ in the Saanen goat, respectively, and these values were similar to the goat (27).

It has been reported that GCT is caused by the combination of the last ganglion cervicale with the first (33), second $(16,27)$ or third (32) ganglia thoracica. In Saanen goats, the same ganglion usually formed by the coalescence of the last ganglion cervicale and first ganglia thoracica. In one sample, the second ganglia thoracica also participated in the formation of GCT. Kabak et al. (16) has reported that one branch of each extended to the ventral branches of the last $n$. cervicalis and second n.thoracalis from GCT, and two branches extended to the ventral branch of the first thoracal n. spinalis. In this study, 
similarly to the literature $(17,27,32,33)$, it was observed that one branch participated in the last cervical $n$. spinalis and first thoracal $\mathrm{n}$. spinalis. In one sample and on the left side, the extending of one branch to the ventral branch of the 7 th cervical $\mathrm{n}$. spinalis from GCM considered as a significant difference. The presence and distribution of the other branches leaving the ganglion were consistent with the literature $(16,17,27,32,33)$.

In this study, immunohistochemical examination of GCC, GCM and GCT revealed that D $\beta H, N Y P, T H$ and SP antibodies were immunopositive. The immunopositivity of SP varies between species and ganglions. It has been reported that SP does not show immunoreactivity in pig GCT (13), in sheep (2) and dog GCM (8) and in rat GCC (4). The immunopositivity observed in all ganglia was an important difference for SP antibody in our study. While D $\beta H, N P Y$, and TH antibodies have showed intense immunopositivity in GCM of sheep (2), it has been expressed that only NPY antibody has showed intense immunopositivity in pig (13) and cat (24) GCT, in dog ganglia trunci sympathici (8) in rat GCC (20). In the Saanen goats, three antibodies were observed to be positive and intensely stained in all the ganglia. This situation can be interpreted as having intensively synapses of sympathetic nerves in all ganglia.

In conclusion, the shape, size and location of cervical sympathetic ganglia (GCC, GCM and GCT), the nerve branches separating from ganglion, and the relation between these branches extremite and peripheral organs and vessels determined in detail in Saanen goat. Although there were some minor differences in shape, size, location of GCC, GCM and GCT and major nerves and interconnected branches separated from ganglion in Saanen goats, our results were observed to be generally consistent with the literature. Besides these similarities, it was remarkable some different findings. One of these was that the nerve branches separated from caudodorsal of GCT did not see. The other one was a branch extending from GCM to both the ventral branch of the 7 th $n$. cervicalis and the $n$. vertebralis in one sample. Also, $\mathrm{D} \beta \mathrm{H}$, NPY, TH and SP showed immunopositive reaction in all examined ganglia. We think that the findings obtained as a result of this study will contribute to the literature of the anatomy and will be a source for the studies to be made about the subject.

\section{Acknowledgements}

We declare that, this study was financially supported by Scientific Research Projects Committee (Project number: PYO.VET.1904.12.008), Ondokuz Mayıs University, Samsun, Turkey.

\section{References}

1. Akers RM, Denbow DM (2013): Anatomy and Physiology of Domestic Animals. Markono Print Media Pte Ltd, Singapore.

2. Arciszewskia MB, Wasowicz K (2006): Neurochemical properties of the middle cervical ganglion in the sheep. Ann Anat, 188, 75-83.

3. Baffi J, Görcs T, Slowik F, et al. (1992): Neuropeptides in the human superior cervical ganglion. Brain Res, 570, 272278.

4. Bergner AJ, Murphy SM, Anderson CR (2000): After axotomy, substance $P$ and vasoactive intestinal peptide expression occurs in pilomotor neurons in the rat superior cervical ganglion. Neuroscience, 96, 611-618.

5. Criscione L, Wyss P, Stricker-Krongrad A, et al. (1998): The pharmacology of neuropeptide $Y$ (NPY) receptormediated feeding in rats characterizes better Y5 than Y1, but not Y2 or Y4 subtypes. Regul Pept, 75- 76, 363-371.

6. Cui-Sheng, Wang JL, Xie ZM (1998): The gross anatomy of the cranial cervical ganglion and its branches in the Bacterian camel (Camelus bactrianus). Vet Res Commun, 22, 1-5.

7. Çakır A (2001): The morphology of cranial cervical ganglion in the New Zealand Rabbit. Vet J Ankara Univ, 48, 83-87.

8. Darvesh S, Nance DM, Hopkins DA (1987): Distribution of neuropeptide-like immunoreactivity in intact and chronically decentralized middle cervical and stellate ganglia of dogs. J Auton Nerv Syst, 21, 167-180.

9. De Felipe C, Herrero JF, O'Brien JA, et al. (1998): Altered nociception, analgesia and aggression in mice lacking the receptor for substance P. Nature, 392(6674), 394-7.

10. Ebner K, Rupniak NM, Saria A, Singewald N. (2004): Substance $P$ in the medial amygdala: Emotional stresssensitive release and modulation of anxiety-related behavior in rats. Proc Natl Acad Sci, 101(12), 4280-4285.

11. Fujisawa K, Ito Y (1982): The effects of substance $P$ on smooth muscle cells and on neuro-effector transmission in the guinea-pig ileum. Br J Pharmacol, 76(2), 279-290

12. Gibbins IL, Jobling P, Messenger JP et al. (2000): Neuronal morphology and the synaptic organization of sympathetic ganglia. J Autonomic Nervous System, 81, 104-109.

13. Happola O, Lakomy M, Majewski M et al. (1993): Distribution of neuropeptides in the porcine stellate ganglion. Cell Tissue Res, 274, 181-187.

14. Kabak M, Orhan İö, Hazıroğlu RM (2005): Macro anatomical investigations of the cranial cervical ganglion in domestic pig (Sus scrofa domesticus). Anat Histol Embryol, 34, 199-202.

15. Kabak M, Onuk B (2010): Macro anatomical investigations of the cranial cervical ganglion in Roe Deer (Capreolus capreolus). Vet J Ankara Univ, 57, 1-6.

16. Kabak M, Onuk B, Demirci B (2015): Macroanatomical investigation of the cervicothoracic ganglion in Roe Deer, Capreolus capreolus. Pakistan J Zool, 47(6), 1555-1561.

17. Kalsey G, Mukherjee RN, Patnaik VVG (2000): $A$ comparative study of cervical sympathetic chain. J Anat Soc India, 49, 26-30. 
18. Kara CO, Topuz B (2002): Horner's syndrome after excision of cervical sympathetic chain schwannoma. Otolaryngol Head Neck Surg, 127, 127-128.

19. Karasek M, Zielinska A, Marek K, et al. (2002): Effect of superior cervical ganglionectomy on the ultrastructure of pinealocytes in the Djungarian hamster (Phodopus sungorus): quantitative study. Neuro Endocrinol Lett, 23, 443-446.

20. Karhula T (1995): Comparison of immunohistochemical localization of [Met5] enkephalin-Arg6-Gly7-Leu8, [Met5] enkephalin, neuropeptide $Y$ and vasoactive intestinal polypeptide in the superior cervical ganglion of the rat. J Auton Nerv Syst, 51, 9-18.

21. Kennedy JM, Zochodne DW (2002): Influence of experimental diabetes on the microcirculation of injured peripheral nerve: functional and morphological aspects. Diabetes, 51(7), 2233-2240.

22. Kim JJ, Chung RK, Lee HS, et al. (2010): The changes of heart rate variability after unilateral stellate ganglion block. Korean J Anesthesiol, 58(1), 56-60.

23. Kokot F, Ficek R (1999): Effect of neuropeptide $Y$ on appetite. Miner Electrolyte Metab, 25(4-6), 303-305. Abstract

24. Kummer W, Heym C (1988): Neuropeptide distribution in the cervico-thoracic paravertebral ganglia of the cat with particular reference to calcitonin generelated peptide immunoreactivity. Cell Tissue Res, 252, 463-471.

25. Luna LG (1968): Manual of Histologic Staining Methods of the Armed Forces Institute of Pathology. McGraw-Hill book Company, New York.

26. Maeda KI, Mori Y, Kano Y (1986): Superior cervical ganglionectomy prevents gonadal regression and increased plasma prolactin concentrations induced by long days in goats. J Endocrinol, 110(1), 137-144.

27. McKibben JS (1975): Autonomic nervous system. 11511161. In: R Getty (Ed), Sisson and Grossman's The Anatomy of The Domestic Animals. W.B. Saunders Company, Philadelphia.
28. McManis PG, Schmelzer JD, Zollman PJ, et al. (1997): Blood flow and autoregulation in somatic and autonomic ganglia. Comparison with sciatic nerve. Brain, 120(3), 445449.

29. Monteiro ML, Coppeto JR (1988): Horner's syndrome associated with carotid artery atherosclerosis. Am J Ophthalmol, 15, 93-104.

30. Nomina Anatomica Veterinaria (2017): International Committee on Veterinary Gross Anatomical Nomenclature (ICVGAN), Published by the Editorial Committee, Hannover.

31. Ozgel O, Kurtul I, Dursun N (2004): On the gross anatomy of the cranial cervical ganglion of the donkey (Equus asinus) in Turkey. Vet Res Commun, 28, 261-266.

32. Ozgel O, Duzler A, Dursun N et al. (2009): The Morphology of the Cervico thoracic sympathetic system in donkeys (Equus asinus L.). Anat Histol Embryol, 38, 139144.

33. Pather N, Partab P, Singh B et al. (2006): Cervicothoracic ganglion: its clinical implications. Clin Anat, 19, 323-329.

34. Shao BP, Ding YP, Xie ZH, et al. (2007): The cranial cervical ganglion and its branches in yak (Bos grunniens). Vet J, 173, 174-177.

35. Stromberg MW (1965): The autonomic nervous system. 634-636. In: ME Miller, GC Chistensen, HE Evans (Ed), Anatomy of the Dog. W.B. Saunders Company, Philadelphia.

36. Yu JH, Burns SM, Schneyer CA. (1983): Salivary secretion induced by substance P. Proc Soc Exp Biol Med, 173(4), 467-70.

Geliş tarihi: 04.06.2018 / Kabul tarihi: 12.02.2019
Address for correspondence:
Assoc. Prof. Dr. Burcu ONUK
Ondokuz Mayıs University,
Faculty of Veterinary Medicine, Department of Anatomy
Samsun, Turkey
e-mail: burcuonuk@omu.edu.tr 